\title{
Epistemological Contributions Derived from an Investigative Method in an Experimental Class in the Study of Hooke's Law
}

\author{
Osmar Henrique Moura da Silva ${ }^{1(0)}$ \\ Carlos Eduardo Laburú ${ }^{1}$ \\ Sérgio Camargo ${ }^{2}$ \\ Airton Acácio Castilho Chistófalo ${ }^{3}$ \\ 1 Universidade Estadual de Londrina (UEL), Centro de Ciências Exatas, Departamento de Física, \\ Londrina, PR, Brasil \\ 2 Universidade Federal do Paraná (UFPR), Setor de Educação, Departamento de Teoria e Prática de \\ Ensino, Curitiba, PR, Brasil \\ 3 Governo do Estado de São Paulo, Secretaria da Educação do Estado de São Paulo, São Paulo, SP, Brasil
}

Received for publication on 5 Sep. 2018. Accepted, after revision, on 16 Oct. 2018.

\begin{abstract}
Insofar as the students' conceptions of the nature of science are by the educator's conduct about the construction of scientific knowledge and thus can be modelled even subconsciously in the classroom environment, it becomes imperative cautious adoption of methodologies with epistemological visions related explicitly or implicitly. For this reason, this research performs the application of an investigative method, by study Hooke's law experimentally in high school, the analysed results allow to characterise the benefits of the strategy in epistemological terms. More specifically, after this application, a structured questionnaire served to collect information from the students, evaluating in this context the percentage of the class that, in the majority, was in fundamental conceptions that diverged from the empiricist-inductive side. This view is philosophically and educationally undesirable and remains in science education, according to the literature in the area, more influenced by the unpreparedness of teachers in the sense treated here. The study hopes to contribute with research line that intercalates contemporary reflections of the philosophy of science in pedagogy in order to favour initial and/or continuing teacher training.

Keywords: Pedagogical Strategy, Investigative Method for Experimental Class, Hooke's Law, High School, Physics Teaching.

\section{Contribuições Epistemológicas Decorrentes de um Método Investigativo em Aula Experimental no Estudo da Lei de Hooke}

\section{RESUMO}

Na medida em que as concepções dos estudantes da natureza da ciência são influenciadas pela conduta do educador acerca da construção do conhecimento científico e que assim podem ser
\end{abstract}

Corresponding author: Osmar Henrique Moura da Silva. Email: osmarh@uel.br 
modeladas inclusive de modo subconsciente no ambiente de sala de aula, torna-se imprescindível a adoção cautelosa de metodologias com propositadas visões epistemológicas relacionadas explícita ou implicitamente. Por tal consideração, esta pesquisa realiza a aplicação de um método investigativo, ao estudar experimentalmente a lei de Hooke em nível médio de ensino, cujos resultados então analisados permitem caracterizar os benefícios da estratégia em termos epistemológicos. Em específico, após essa aplicação, um questionário referencialmente estruturado serviu para coletar informações dos estudantes, em que se avaliou nesse contexto o percentual da turma que, em sua maioria, mostrou indícios de concepções básicas que divergiram da vertente empirista-indutivista. Visão esta indesejada filosófica e educacionalmente e que permanece no ensino de ciências, segundo a literatura na área, mais por influência do despreparo de professores no sentido aqui tratado. Espera-se assim contribuir com a linha de pesquisa que intercala reflexões contemporâneas da filosofia da ciência na pedagogia de modo a favorecer formações iniciais e/ou continuadas de professores.

Palavras-chave: Estratégia Pedagógica, Método Investigativo para Aula Experimental, Lei de Hooke, Ensino Médio, Ensino de Física.

\section{INTRODUCTION}

It is a consensus that the teacher's epistemological conception derives the understanding of science taught in the classroom by him or her (Chinelli et al., 2010, p.18; Allchin, 2004, p.188; Matthews, 1994, p.83; Whitaker, 1979, p.108). Interestingly, however, decades ago that studies in scientific education demonstrate how "visions have already overcome about the nature of science and scientific work has been one of the main obstacles for the renewal of science teaching" (Chinelli et al., 2010, p.18). According to Acevedo Díaz (2008), after approximately fifty years of research about this theme, it is stated that the students of different levels of education, as well as teachers, do not have, in general, appropriate conceptions about the nature of science; consequently this, including, due to the latter not to concern educationally with the subject compared to other more traditional contents (ibid.). As exemplary corroboration to the various results until then disclosed in this context, Apostolou and Koulaidis (2010) criticized the epistemological notions of science teachers about the scientific method (and the demarcation), change and status of scientific knowledge, to conclude that a mix of empirical- trends-inductivist trends proved to be dominant position before the little support to the hypothetical-deductive vision. This goes hand in hand with the analyses of Labatini-Tera et al. (2014), whose research aimed to characterize the epistemological descriptions of Physics undergraduates after having read some scientific articles, by which it is important to realize how future teachers might reproduce a deformed and stereotyping vision of the process of knowledge construction in the classroom. Therefore and reaffirming that "the interfaces between epistemologies and the teaching of the sciences, in practice, are ignored, even today, after decades of discussion in the literature about the teaching of sciences" (Moreira \& Massoni, 2016, p.1), the present study falls within the line of research that merges contemporary reflections of the philosophy of science in the pedagogy in a way to contribute to the initial and continuing training of teachers to help modify this inappropriate condition. More precisely, this research carries out the implementation of an investigative method 
(Silva \& Laburú, 2016) to study the Hooke's law experimentally in high school level of education, 1 whose results then analysed allow to characterize the advantages of the strategy in epistemological terms, thus suggested a pragmatic approach to the science educator interested in practical /experimental classes.

\section{REASON FOR THE STUDY}

While teaching-learning strategy, the experimentation has been advocated in the teaching of Physics for some decades (Biscano \& Camargo, 2012), whose incorporation has been occurring through different conceptions of science, teaching and learning (Higa \& Oliveira, 2012). Essentially, it is essential to distinguish among the concepts of pedagogical strategies: the one with experimental activity considered illustration of theory with experimental activity for personal discovery, and the experimental activity to introduce students in the processes of science (Ferreira, 1978). In the first of them, theoretical classes are begun, in which the contents are passed to the students, who receive them passively, without generally questioning them or discussing them. The teacher, in turn, leads students to problematize such content, since it reproduces the model of education that he or she received in his or her major (Camargo, 2003). In the practical classes, after the theoretical ones, students are guided to demonstrate the laws and theories, then 'unquestionable', presented with an authoritarian sense either by the teacher or by the textbook. The second of them relies on a model of learning that leads the student to individually 'build' scientific knowledge autonomously in interaction with the environment, whose cognitive outcome is the fruit of an inductive process and is originated from the common sense. In the third one, the experimentation is characterised as a means of entering the apprentice in the processes of science, when at the same time that the abstraction is promoted of the conceptual content that aims to develop in the subject ability of "doing science". As discriminated above and though with this latest strategic approach indicate greater requirement of epistemological involvement, it is worth idealizing each one of them in an epistemological-pedagogical context, in which the epistemological whether mean the involvement of a conception of science 2 while teaching by if you want to mean a conception of curriculum (Amaral, 1997). 3 Therefore, reasonable guidelines about the construction of scientific knowledge and the nature of science in students require a cautious adoption of methodologies with purposeful epistemological visions related explicitly or implicitly. Due to the above mentioned, even though limitations of these three strategic conceptions of incorporations of experimentation as pedagogical proposals have been discussed in the literature, it is considered herein the guiding understanding of not restricting the simple realization of experimental activities, exemplifying in such cases, the closed demonstrations and

\footnotetext{
1 This work is part of a larger research, by which the pedagogical strategy was structured by applying it in two distinct content for analysis: Boyle-Mariotte law (Silva \& Laburú, 2016) and Hooke's law.

2 Covering concepts such as reality, method and scientific knowledge, and relations between different knowledge.

${ }_{3}$ Covering concepts of learning, consideration and positioning of the students' prior knowledge, and relations between content and method.
} 
the laboratories for verification and confirmation of the theory previously defined (Oliveira et al., 2010; Galiazzi \& Gonçalves, 2004, p.331; Araújo \& Abid, 2003, p.177). According to Oliveira et al. (2010, p.32), such limitation prevents the student from an 'incentive to discussion, criticism and autonomy". Thus, before the pedagogical bias of this research methodology whose pragmatic structure will be presented in the next section, it is now imperative to reflect on the epistemological bias inserted in a strategic approach, since "whenever a science is taught, a philosophy, up to a certain point, is also taught" (Matthews, 1994, p.83).4

In the posterior trend to the positivism of Augusto Comte (1798-1857), called logical positivism or logical empiricism (Abbagnamo, 2000, p.328), the data depart from observation and experimentation being characterized as neutral (not contaminated or selfsufficient), and allowing, by induction, the establishment of laws which constitute the scientific knowledge. However, the criticisms to such foundations were so numerous by Popper (1972) and others, that the philosophy of contemporary science does not ignore the role of ideas and hypotheses generated by the human mind as a guide to observation and experimentation. Currently, it is sensible to conclude in this context that the postpositivist epistemologies converge to, at least, two points: 1) knowledge is not originated and obtained exclusively from observation and experimentation, as if it were a truth extracted from the facts, however, any intentional observations are impregnated of theory (Andersson, 1984, p.216; Kuhn, 1970, p.6; Popper, 1970, p.64; Hanson, 1975, p.130 and $131)$; 2 2) There is a transitoriness of scientific knowledge by changes in their historical reflections on the production and development of knowledge. Thus, they agree that the condition necessary for scientists to abandon a theory is the availability of another one capable of replacing it (Kuhn, 1994, p.108; Popper, 1972, p.92; Lakatos, 1970, p.146). Upon limiting solely on these points, any contemporary epistemology should be the basis for the realisation of analogies to the instruction of physics contents (for example). The first point is like the interaction of students with the most different phenomena from their pre- existing ideas or "theories" (spontaneous conceptions) not being designed as a kind of cognitive vacuum that only appropriate of physical knowledge from the professor's "talking", books and even the experimental activity.6 The second point refers to the conceptual evolution which is expected to achieve in the apprentices' minds during the instruction, being required, for this reason, that they know a new law, a concept, etc. As the ideal of education in this sense, the new scientific knowledge

\footnotetext{
${ }_{4}$ Whitaker (1979) argues that one should not dismiss the possibility of high incidence of a notion of science, which comes to be assimilated subconsciously instead of directly. What occurs, in this understanding, is that guidelines on the development of a law or theory (Newton's laws, the principle of Huygens, among others) may cause an improper connection between, for example, the principle of Huygens and its consequence. For the author (ibid., p.108): "The student can infer that the consequence was obvious to Huygens' or 'immediately obvious to any intelligent person, for Huygens producing (deducting) his principle from the result of repeated experiments in the laboratory.

${ }_{5}$ According to Chalmers (1994, p.61): "The empiricist hypothesis to what point an objective observation for science is at our disposal has been harshly criticized by philosophers of science in recent decades".

${ }_{6}$ Or in the words of Paulo Freire (apud Delizoicov, 1996), as if they were "empty containers" in which must be the "deposit of contents".
} 
being learned in the background of the students exceed those of being common or spontaneous conceptions.

By this epistemological orientation, it is sensible to establish a strategic assessment of the three conceptions already dealt with. Thus, while the experimental activity characterised as an illustration of the theory directs the apprentice to prove a law or theory initially taught in an authoritarian manner, favouring an impression of unquestionable truth, the experimental activity for personal discovery is in line with the vision of post-positivist science in performing aspects of the empiricistinductivist model.7 Thus, there remains the third strategic design a greater acceptance of education than the previous ones by the feasibility of inspirations in post -positivist epistemological views in the sense here clarified. This filing that makes merit taking into account "one of the most important objectives of science education that students of primary/secondary education come to acquire a better understanding of the nature of science" (Rosa \& Rosa, 2010, p.1). Such judgement is valid due to the fact that "One of the most important goals of scientific education is to make the basic/high school to achieve a better understanding of the science nature" (Rosa \& Rosa, 2010, p.1).

In this sense, however, architecting the experimentation to introduce students in the processes of science, placing a "scientific method" as support for the abstraction of conceptual content, deserves to be further discussed. In scientific education, although the binding of the scientific method (MC), designated by acronyms O.H.E.R.I.C. (Observation, Experience, Results, interpretation, Conclusion), has seemed to 'match' to the attempt of dissolution in seeking answers to how to teach students to "doing science" (Giordan, 1999), thus proved to be epistemologically challenged by misleading conclusions justified in comments formally logical and impartial.. In this case, the main criticism to MC lies in the fact that it is begun with the observation that precedes the theory (Millar, 1991), generating, in educational terms, certain myths about science and scientific research, namely: the observation provides direct and assured access to knowledge; science begins with the observation; science advances by induction; experimentation is decisive; science covers discrete and generic processes; scientific research corresponds to an algorithm of procedures; science is a practical objective; all scientists have these attitudes (Hodson, 1998). In this context, contemporary epistemologies in the philosophy of science favours the renunciation of $\mathrm{MC}$ in the classroom and lead to an educational perspective in which teaching how to "do science" has greater meaning through the realization of "investigations" (method of solving problems), by which they seek to characterize three main elements: Question, Hypothesis and Experience (Giordan, 1999). And so that there is no undue interpretation with pronounced similarities among the steps of $\mathrm{MC}$ and the characteristics of a

\footnotetext{
7 It is a consensus between epistemologists and researchers in scientific education about the misconception that is done upon spreading spread educationally the empiricist-inductivist conception as a way of conceiving the scientific work.
} 
"research", it is necessary to clarify that: 1) In e MC the observation is objective and independent of theory and the experiences of the observer. The concept of research, the investigation is dependent on the previous ideas of who performs it;

2) Therefore, $\mathrm{MC}$ is intended to confirmation of hypotheses that are believed to be formulated based on the comments initially made, and that there is the formulation of a problem, which is taken as originating from the observation. Through the influence of this understanding given to observation, the resolution of the problem is less appreciated, and the achievement of the expected results are more appreciated (Cachapuz et al., 2000). Differently, in the field of research, there is a fundamental role to problems to the extent that guide the subsequent work, being recognized, as well as the assumptions, as conditioned to prior theories or ideas that the subject carried on the natural world. It follows that traditional details of MC can be present in an investigation, but with a very different meaning.

By the way, it is essential to exemplify a pedagogical interest of apparent rescue of MC proposed by Marsulo and Silva (2005), reworded in a diagram which highlights the viability not only of originating from the formulation of the problem but also originating from hypotheses, without necessarily having to define a problem; but that, in this case, they recommend to bind the reflection: "what type of questioning does that hypothesis allows us to do?". Thus, there is a defence of authors (ibid.) in the testing of new distinct logics for movements among the constituent elements of $\mathrm{MC}$, which leads to the reconstruction of assumptions with explanatory ability in solving problems. However, toward the practice of this integrality of steps in an educational strategy, Laburú (2003) defends a probable failure of a methodology of research in the lab activities, originated from the open problems, based on the dialogic discourses 8 that do not emphasise the vital role of the univocal discourse. Accepting such recommendations and considering the indications that many teachers in this context are carelessly inclined to caricaturing the development of science as initiated by the observation9 (Maldaner, 2000), it is investigated herein the results of the application of an educational strategy that respects the concept of research discussed above to apply an investigative method in a real-life situation of classroom, whose structure is given below.

\footnotetext{
${ }_{8}$ According to Mortimer and Scott (2002), in the dialogical dimension the students' different points of view on the subject are prioritized, even if they are not in accordance with the scientific concepts. This dimension, which considers more than a voice, allows the interanimation of ideas. Thus, in a dialogic discourse it is expressed more than one point of view, different thoughts and opinions are accepted during the discussion. Whereas the discursive approach of authority is characterized by reference to scientific knowledge. In the latter, the educator takes possession of the univocal discourse, not occurring the intercommunication of ideas. The term authority refers to the voice used to direct the discourse of scientific bias, that is, the "voice of science". (ibid.).

${ }_{9}$ Pedagogically "the empiricist conception associated with the belief that scientific knowledge is a true, unquestionable knowledge" (Lôbo, 2012, p.431) should be rejected, as it remains worrying about "The idea that scientific knowledge is obtained directly from the experimental results is still very present in the teaching of the sciences and between teachers and students" (ibid.).
} 


\section{THE PEDAGOGICAL STRATEGY AND ITS APPLICATION AS AN INVESTIGATIVE METHOD}

Although one might characterize the present experimental activity, based on the methodology of research, as initiated by a genuine problem 10 raised by the teacher, 11 some preliminary clarifications are still indispensable by him or her (Laburú, 2003), below exemplified in a first step established of what is forged as "observation loaded with theory". The next steps, dependent on the good development of this, soon after being discussed when investigating the Hooke's law $(\mathrm{F}=\mathrm{k} . \mathrm{x}) .12$

This initial stage can be defined as "Presentation of the Phenomenon", in which the teacher directs a reflection with the students about the behaviour of the spring.13 At this time, the teacher led the students' attention for the variables to be examined: the strength of mass acting in the spring and the respective displacement of the same. In practice, he or she benefited from the own experiment to be used and which enabled to demonstrate the variations of such magnitude, while he took the opportunity to explain and take questions from experience. Qualitatively, the teacher tried to indicate the type of relationship among the variables in focus, becoming aware of their experimental limits, considered an essential understanding for obtaining and monitoring, at a later stage, the hypotheses formulation. As essential step, therefore, it is up to the teacher to ensure that students are instructed with appropriate prior knowledge and that on occasion involves: the physical concepts of the variables weight force $(\mathrm{F})$ and displacement $(\mathrm{x})$, a basic notion of experimental errors (systematic and random), 14 the mathematical understanding of elementary algebra for manipulation of equations, 15 and the understanding of the functioning of the experimental apparatus employed.

The second step is to launch the research problem within a reasonable degree of difficulty to the class. In the situation, it is recommended that the question that was asked: What is the relation (equation, formula, law, function, etc.) between the weight force $(F)$ and displacement $(x)$ suffered by the spring? It is worth stressing

10 In accordance with the concept of research (Giordan, 1999).

${ }_{11}$ Whose proposal proceeds in a way that there is no theoretical lesson preceding the experiment for which the student will remain unaware of the response of the problem, because, otherwise, the experiment would represent an activity of mere application or verification of theory, and not of research.

12 The traditional experiment was constituted of a universal support with cable, where was fixed the edge of a plastic spring suspended vertically, at the lower end, adapt a small pot where you add measured masses (currencies).

${ }_{13}$ Describing that the Hooke's law to be investigated is the existing restorative force, in this case, of the spring to be compressed or distended. For small deformations there is the elastic regime, allowing the spring to return to its original shape when the force that generates the deformation is ceased. For large deformations, the material (spring) can acquire permanent deformation, characterizing the plastic regime, a situation that does not belong to Hooke's law to be studied.

${ }_{14}$ In this class, most students already had a notion of experimental errors that occurred due to the use of quantitative experiments aimed to study uniform rectilinear motions (URM).

15 It is laid down in the syllabus that the average level of education students should already have a skill in that direction. In practice, however, the question may be difficult to be answered and not have clear meanings to most of the students. Therefore, previously in this step, related attempts are valid to clarify providing examples from physical expressions that they have already experienced, calling attention to relations among directly proportional and inversely proportional quantities. Discussions in this sense help in preparing the student with "The idea of mathematical function, formula, equation, which should assume a link among variables that, upon being applied to reality, express a physical law, i.e., a necessary regularity of a natural phenomenon" (Laburú, 2003, p.25). 
the need to be now clarified the term relation, since, according to Laburú (ibid.), this is one of the biggest obstacles in research, and attention to the prescribed in the last footnote to go to the next step, which is the raising of hypothesis.16 In the third step, it is latent in the educational conduct an obedience to attempt to foster in students a lesson implied of being the intellect, the person responsible for placing the acquisition of ideas and that these are not initially evident by means of the senses. 17 The progress of the step, as predicted (ibid.), the teacher intervened by univocal discourse explaining the reasoning in two hypotheses $\left(\mathrm{F} / \mathrm{x}=\mathrm{k} ; \mathrm{F}_{2} / \mathrm{x}=\mathrm{k}\right)_{18}$ for tests, favouring those early examples the understanding of what was empirically tried to investigate as well as the unfolding of new hypotheses in the students' minds. Among the hypotheses mentioned by the students, the teacher must choose one more (F. $\mathrm{x}_{2}=$

$\mathrm{k}$ ) as a third alternative to test, but that was then derived from the class imagination. This is needed due to being pedagogically consistent to give a choice to less complex mathematical hypotheses in conjunction with the law that intends to be corroborated experimentally. By truism, similar alternatives to the type $\mathrm{F}+\mathrm{x}=\mathrm{k}$ or $\mathrm{F} . \mathrm{x}=\mathrm{k}$ lead to specific complications that need to be promptly resolved in a univocal ${ }_{19}$ way, although this exemplary clarification will also assist the process of elaboration of hypotheses. Thus, it is crucial to establish reflections during the elaborations of hypotheses as belonging to the cognitive nature of the "possible", since this is associated with the mental process of constitution of possibilities.

In the fourth step, it is conceived the work plan, which then aimed the teacher to lead the students' attention to manual tasks. It is suggestible here is a question like the one occurred: What should I do in practice to test the first hypothesis? Being agreed that the forces of weights and the respective displacements of spring are the measures to be carried out, the first data gathering had the performance of the teacher more directly as an exemplification.20 The path that proceeded to test the hypothesis to be corroborated $(\mathrm{F} / \mathrm{x}=\mathrm{k})$ and the others to be forged $\left(\mathrm{F}_{2} / \mathrm{x}=\mathrm{k} ; \mathrm{F} / \mathrm{x}_{2}=\mathrm{k}\right)$. There was guidance from the teacher to the constitution of the data in table 1, in columns "orderly" showing the masses and their displacements, well organised for use in the next step. The results presented in table 1 refers to the values found by the group 1 (formed by 5 students), which was more closely accompanied by the teacher and that was constituted the table displayed on the blackboard to study with the class.21

\footnotetext{
${ }_{16}$ Raising the question and realizing the students the need to discover the value of a constant experimental in proposed activity, it is up to the teacher, in support of understanding in this sense, to redeem the students 'memories of previous situations when they experienced in laboratory physical expressions that used when they found constant values. In this case, the professor had tried to make an analogy with the expression already studied for obtaining a constant value of a body speed in URM, which proved to be didactically timely. 17 Thus, distancing themselves from an empiricist/inductivist posture.

${ }_{18}$ Being $\mathrm{k}$ a constant. Note.: At this time, the differences between a variable and a constant are already found. ${ }_{19}$ In addition to those repeated formulations that can arise in another format as $F_{2} / k=x$ or $F / k=x$. ${ }_{20}$ What allowed them to go on operationalizing (how to make) new measures, giving them the opportunity to solve doubts which until then could not be resolved.

${ }_{21}$ Note.: In this activity, in terms of data, the results of the remaining groups were evaluated separately by the teacher.
} 
Table 1

Table by which the teacher instructed the students.

\begin{tabular}{|c|c|c|c|c|}
\hline Masses (x 7.2g) & Displacement $(\mathbf{c m})$ & $\mathbf{k}(\mathbf{g f} / \mathbf{c m})$ & $\left.\mathbf{k}(\mathbf{g f})_{2} / \mathbf{c m}\right)$ & $\mathbf{k}\left(\mathbf{g f} /(\mathbf{c m})_{2}\right)$ \\
\hline 1 & 1.05 & 6.86 & 49.37 & 6.53 \\
\hline 2 & 2.15 & 6.69 & 96.44 & 3.11 \\
\hline 3 & 3.25 & 6.65 & 143.55 & 2.04 \\
\hline 4 & 4.40 & 6.55 & 188.50 & 1.49 \\
\hline 5 & 5.40 & 6.67 & 240.00 & 1.23 \\
\hline 6 & 6.60 & 6.55 & 282.76 & 0.99 \\
\hline 7 & 7.60 & 6.63 & 334.23 & 0.87 \\
\hline 8 & 8.80 & 6.55 & 377.01 & 0.74 \\
\hline 9 & 9.80 & 6.61 & 428.47 & 0.67 \\
\hline 10 & 10.90 & 6.61 & 475.59 & 0.66 \\
\hline 11 & 11.85 & 6.68 & 529.33 & 0.56 \\
\hline
\end{tabular}

In the fifth step, the data are analysed the data, which can be considered nothing unusual in this school level students have difficulties interpreting if the ratio $\mathrm{F} / \mathrm{x}$ is constant or not due to data not being numerically similar (Laburú, 2003, p.249). Here it was necessary to intervene again with univocal discourse to formulate the response of the initial problem, whose thinking was the understanding that the values of the ratio $\mathrm{F} / \mathrm{x}$ are perceived as characterising an experimental float around a value considered constant.22 The univocal discourse applied to this circumstance in an instructive way 23 is justified, because, according to Lubben and Millar (1996), the idea of fluctuation around an average value is hard to be understood by high school students. Whereas through an explicit comparison with the other two hypotheses that these values systematically grow or diminish, the teacher directed the students' attention to realise that there is an average number which should be imagined as a result of non-fluctuation of values.

The sixth step involves the final moment in which the conclusion is carried out that, by implication from the previous step, the objective is at least a prudent judgment of the results found.24 In this sense, now going beyond the limits of the dialogic discourse

22 In that comments of reasonable and experimental errors and inherent in the situation were associated. ${ }_{23}$ Here it is important to demystify the mistaken understanding of students, as Allie et al. (2001), in which each measure is independent of the other, being accurate, by themselves, without needing to be combined in some way.

24 It is still important to predict anomalous situations that the educator can encounter when groups have negative results, that is to say, with measures that do not characterize a fluctuation of values due to experimental problems. Predicted examples comprise from a simple confusion in the quantity of masses similar added, or error of observation/ annotation of $\mathrm{mm}$ or the ruler, and even an unwanted data column in which the ratio $\mathrm{F} / \mathrm{x}$ systematically decrease or increase. In the latter case, Laburú $(2003$, p.205) suggests that 'it would be didactically positive, to the extent that students conclude independently from data, that the tested hypothesis was invalidated...". According to him 
of only providing pieces of evidence of what is liable to take as valid, the teacher led to the conclusion for the expression $\mathrm{F} / \mathrm{x}=\mathrm{k}$ as a response of a planned investigation. The explanation for this behaviour is due to the subsidy to those students who yearn for a direct intervention of the educator to answer the problem and, accordingly, such an attitude is to integrate what was here guided by the teaching.

For this experimental application of this investigative method in the specified content, what exemplifies their viability in the educational episode, it follows then the main objective of this work regarding the study of the possibilities of contributions of this method on the improvement of some students' notions about the nature of science, 25 currently more acceptable in epistemological terms.

\section{The methodology of data collection of the students' notions due to this application}

In order to investigate the effects of such application in this context, a questionnaire was delivered to the students aiming to clarify some of their notions that involve analyses of epistemological nature. Specifically, it was aimed to examine if they showed signs of certain notions that are in line with those frequently observed/disclosed and that are epistemologically criticized, namely: 1) That the knowledge does not come only or primarily from sensory experience and that, in this aspect, the role of creativity and imagination becomes critical; 2) Therefore, an experimental investigation may involve the execution of tests for the alternatives (hypotheses) previously devised. Having said and with apparent logical coherence between these two aspects, in order to identify them in the students two questions were structured, constituting each one of two alternatives that express contradiction between themselves on a specific aspect, but that guide the student to decide for an understanding. Structuring of this questionnaire which is justified even for supporting a better targeting of attention in the answers. Therefore, the methodology of data collection made the students provide two types of answers that cover these aspects upon indicating two related alternatives. This procedure made the apprentices initially indicate, between two alternatives available for each question, nature of knowledge which they agreed. The two questions are formed to cover the subject-object relation, which analytically allows performing a consistency of the alternatives marked by them. It also means, during the analysis, providing an intersection of responses, as, an agreement or disagreement with one aspect in the first question is, respectively, consistent with a disagreement or agreement with another aspect of the second question. Indeed, once

\footnotetext{
(ibid.): "Is it possible to advance in this conclusion, prompting a debate on the possible reasons for these negative results differ from those found by most of groups". In such a circumstance (which did not occur in the present research), this author (íbid.) recommends several worthwhile issues to the teacher to subsidize the apprentices to better interpret their results.

${ }_{25}$ According to Ledermann (1992), the expression "nature of science" in the teaching of the sciences may refer to: the epistemology of science; the science as the path of knowledge; or even to the values and beliefs present in the progress of scientific knowledge.
} 
selected the alternative that most closely identified with their convictions, the student was asked to justify their agreement or disagreement with that aspect there indicated.

In order to provide a more general analysis of the results, confronting the justifications with alternatives marked individually, it was sought to indicate a relative correspondence to any one of the fundamental and antagonistic understandings about the nature of scientific knowledge, namely: empiricist or rationalist character. Namely: on the one hand, the empiricist character is a basic design of science linked to positivism; on the other, the rationalist character is compatible with the post-positivist visions of science.26 To the segment of this analysis, below follows the questionnaire which collected the students' notions.

Question 1 - Mark an alternative that you admit to having occurred in the investigation of the phenomenon.

( ) The hypotheses (or thought alternatives) were first drawn up for after being tested in the experiments;

or

( ) The observation of the results is that it allowed the creation of hypotheses.

Justify.

Question 2 - Indicate the order of the procedures that you understand followed in the investigation of the studied phenomenon.

( ) 1. (Observation) Observed the phenomena related to the weight force and displacement of the spring; 2. (Experimentation) Performed the experiments and observed the results; 3. (Reasoning) Created hypotheses from the results; 4 (Conclusion) Selection of the hypothesis $\mathrm{F} / \mathrm{x}=\mathrm{K}$.

or

( ) 1. (Question) Problem raised from the study of the phenomenon of variables pressure and volume; 2. (Hypothesis) Creation of hypotheses; 3. (Experimentation) Performed the experiments and observed the results; 4. (Conclusion) Selection of the hypothesis $\mathrm{F} / \mathrm{x}=\mathrm{K}$.

Justify.

${ }_{26}$ However, it is necessary to alert to a limitation of this analysis to the extent that the understandings of apprentices in this school level do not contain detailed developments, with characteristics of science configured by a specific epistemology. 


\section{EPISTEMOLOGICAL ANALYSIS OF THE RESULTS OF THE SAMPLE INVESTIGATED AND DISCUSSION}

In principle, the group investigated presented 35 students enrolled regularly, but 11 students were withdrawn in this predicted sample: one by the absence occurred on the day and others by handing the blank questionnaire or very incomplete. Eliminating then those who did not take part in the activity as planned, Figure 1 graphically displays the amounts of alternatives indicated by the students in each question on the questionnaire, now applied to the class with 24 students.

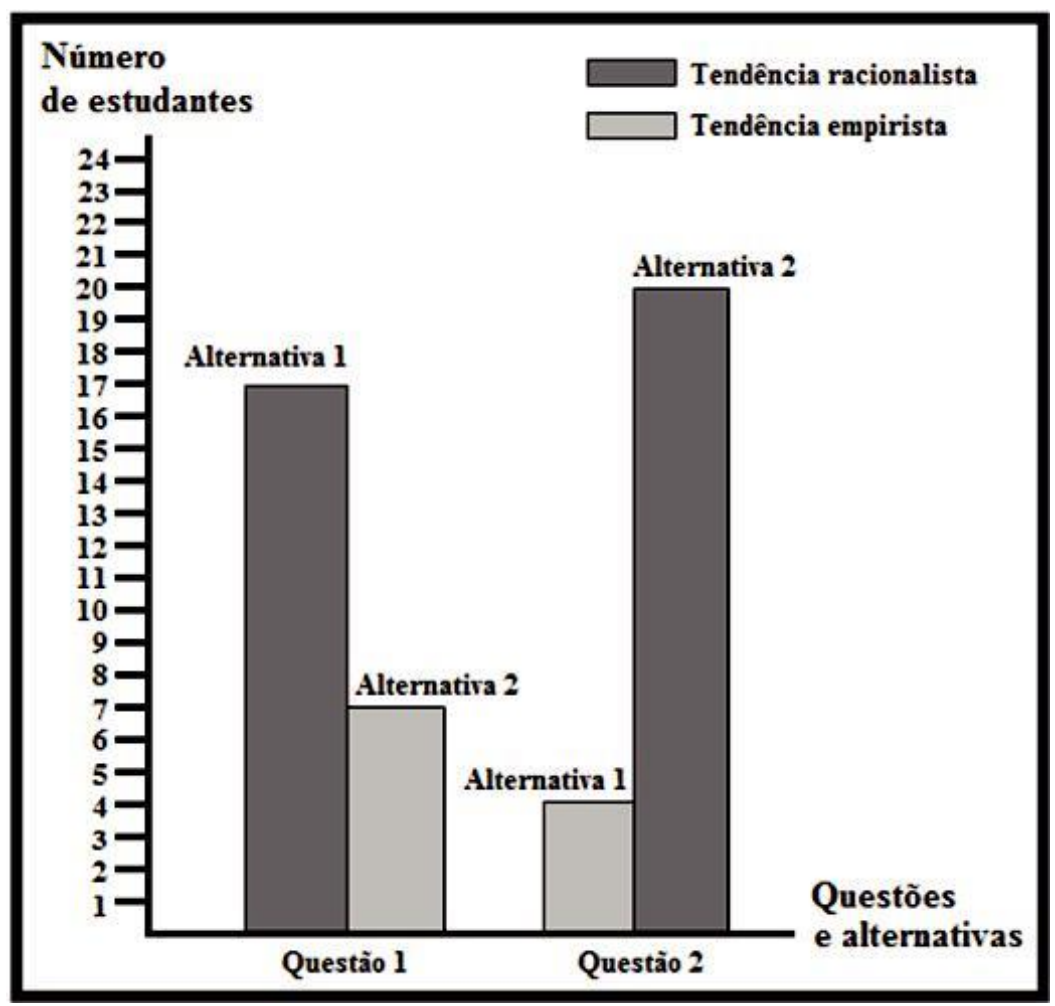

Figure 1. Graphic with the representativeness of the alternatives listed by the students.

For question 1, the results indicate that approximately $71 \%$ of apprentices in the hand of the alternative matched to the rationalist aspect. A meeting of individual comments presented in justifications exemplify typical thoughts found:27 "It is important to create the chance to test them then"; "we built (imagined) a hypothesis and again to see the reality of the experiment"; "my hypothesis has not been tested, and I think it would not

${ }_{27}$ Note: Between parentheses are words added during the analysis aiming at better indicate the meaning of the students' comments. 
work out because the other that the teacher gave was the winner"; "a hefty hypothesis is to analyze in practice how the results are"; "Various hypotheses have been conceived and only after the results (experimental is that) we could evaluate which (of them) is the correct one ". It is possible to assert that such reviews depict potential notions reconcilable to the accession that scientific theories are elaborations covering, in essence, aspects such as the imagination, creativity, intuition, etc.28 Concerning the structuring of the alternatives of question 1, while the first of them purposely displays a logical segment of hypotheses to be tested after initially conjectured by the intellect, the second alternative tends to back up the notion of common sense in which hypotheses are derived from observations of neutral facts. This movement opposed to the visions of elaboration of knowledge to then be reflected, most of the students, those that have marked the first alternative (approximately 71\%), did not characterise any justification which would emphasise a trend to the belief that the knowledge arises from the sensible and impartial observation of facts. As for the other students who joined the second alternative, they might consider some justifications with greater difficulty of interpretation, notable in the following comments: "The observation of the results is important to accept a hypothesis or test another"; " $F / x=k$ was proved as correct by observing the calculated numbers". It would be liable through these reviews, in case these students had marked the first alternative, even trying to judge their references to the results as members of tests for approval or rejection of a theory (or law) in idealised in advance. However, as these two students indicated the second alternative, it was then tried to sort their arguments, next to the others (near 29\%), as grounded in an empiricist vision that several studies warn to prevail in students from this school level.29

Students whose notions were considered as a rationalist in the first question, a naturalness of adhesion to alternative 2 of the second question was observed. In a plausible manner, one reason for this is due to the alternative 1 (question 2) establish a purposeful segment of procedures to direct, by the names "Experimentation" then "Reasoning", a clash with the understanding that they had set out in question 1 . It was found that the totality of individuals that comprised the initial rationalist percentage (71\%) of question 1 was cautious regarding the consistency in this sense, who in the midst of the equivalent justifications are analyzed as follows: "The study (investigation) began by the thought hypotheses and testing the results of each one until hitting (achieving) the right one "; "Hypotheses were first suggested, and we will test them to assess which remained with the reason constant"; "We chose some hypotheses designed and then tested to see the one accepted..."; "It is important to investigate each hypothesis (imagined), because the results that allow showing the one that really works"; "The good alternative is the 2 that was what was done in the classroom, where we created hypotheses that were chosen to take decision of results about which is the best". It could be observed by all the

${ }_{28}$ Compatible with the sense of the phrase: "The theories are our inventions, our ideas - not imposed to us" (Popper, 1972, p.144).

29 Reason why it was analytically tried to highlight more the results found that, and even because they compose the most marked trends to the rationalist aspect. 
justifications of question 2 a decrease in the initial empiricist percentage to almost $20 \%$. The viability of this reduction was a possibility of expectation right in the preparation of this questionnaire, since the second question is distinguished from the predecessor as it emphasizes two sequences of procedures to be confronted and decide which of them happened in investigative activity, being such a reflection forged by the question that showed with the potential to influence them to remember/think better of what happened. This, therefore, explains the fact that some students, first kept with empiricist postures, including among them those who presented explanations of complicated classification as exemplified by the end of the preceding paragraph, report the alternative 2 with clarifications that resonate with the following meaning: "In one hypothesis the values grow, and on the other the values decrease... the only (hypothesis) with numbers kept close is $F / x$ ". This reasoning, however, together with that of the own student (" $F / x=k$ has been proven to be the correct one observing the calculated numbers ") when marked the alternative 2 of question 1 (interpreted with empiricist trend), characterized one of the inaccurate results that precluded this analysis from finishing with a high percentage of desired rationalist character, initially bordering the $71 \%$ of the investigated sample .

\section{FINAL CONSIDERATIONS}

It is possible to perceive in the literature in science education that the concept of research should be promoted as an epistemological alternative superior to MC within the educational perspective by which it is desired teach students how to "do science" during experimental activities. In this context, the present study investigated an exemplary implementation of a pedagogical strategy, whose sequence of steps is a pragmatic way to the science educator with the following merits synthesised in comparison with the reference research proposals and MC.

Regarding the main criticism to MC (O.H.E.R.I.C.), this investigative method joins an essential role to the problems and the chances for being recognised as linked to previous theories or ideas that the individual possesses of the natural world. It was sought, in this sense, to assist a worrying problem which is discussed to persist in science education relevant to the demand to overcome an addiction due to the empiricist position, based on the belief that science is originated from the sensitive, of the observation of facts. Therefore, and considering that there will always be an epistemological conception underlying any teaching situation, to the extent that as it was reporting the pedagogic sequence of procedures that occurred in this strategy, it was sought to defend a lesson implied regarding the importance of the intellect to the establishment of a range of ideas and that they are not obvious first through the senses.

In relation to the concept of research (Giordan, 1999), then spread as consisting of the elements QUESTION, HYPOTHESIS and EXPERIENCE, two points of its original conception are liable to be discussed, namely: 1) in a research it is considered that there 
is not a sequence composed of well-defined steps, but rather a multiplicity of possible sequences, in which data analyzes and open problems blend continuously due to a speech basically dialogic, in which the students "have autonomy in the procedures of research" (Kaline, 2015, p.35); 2) 30 an experience never completely refutes a hypothesis, which in most cases resists, transforming and adapting to the circumstances, only being abandoned by the convergence of various experiences that contradict it (Giordan, 1999). In practice, it is possible to observe and judge that the first point is harmed when it imposes a univocal discourse in a methodology of research in lab activities in a basic level of education. According to Laburú (2003),31 there is a utopian vision of apprentices to be able to "lead" an investigation from an orientation that retains a dialogic discourse between teacher/ student. Thus, an alternation of stages (multiplicity of possible sequences) which takes place through a dialogic discourse might make education more tiring, slow and even without the expected success of "doing science", being more workable in practice to lead students to experience (Act) an (in an) investigation of rather than aim that they perform it with "full autonomy". About this, the present study showed a pragmatic way (a sequence of steps) to apply a methodology of research which, in terms of teaching, was better exemplified to the educator than a proposal for a multiplicity of possible sequences to characterise the course of research. Whereas in relation to the second point, it was demonstrated in this educational methodology (scope) the feasibility of completing a "definitive" corroboration 32 of the hypothesis that the educator aims to teach (scientific concepts focused in school), but with a perspective of embedded investigation in the experimental activity.

Lastly, it is expected that this study will contribute with that science teacher who identifies himself or herself with research methodologies in lab activities and, above that, with the related courses of continuing formation that comprise epistemological issues. Contribution in order to assist, at this educational level the educational goal of learning to investigate, that "involves learning to observe, plan, raise hypotheses, perform measurements, interpret data, reflect and build explanations of theoretical nature" (SÁ et al., 2008).

\section{REFERENCES}

Abbagnamo, N. (2000). Dicionário de Filosofia. Editora Martins Fontes: São Paulo.

\footnotetext{
${ }_{30}$ By intention of strong approximation to the philosophy of Karl Popper.

${ }_{31}$ This author (idid.) performs a broad reflection about research methodologies originated from open problems based on the dialogic discourse characterizing that: it is common a problem raised by the teacher (e.g... 'what is the relation between pressure and volume of a given system?') Such relation is distant from being easily understood, even after the diligence to make it clear, by means of a more univocal speech done by himself or herself before this step; which implies for the teacher to provide the launching of an exemplary hypothesis for the understanding of what such hypothesis is all about, along with the problem, and thus becoming clearer. Indeed, he argues that all aspects of an investigation (phenomenon, problem, hypotheses, work plans, data analysis and conclusions) may lack of educational positions with univocal speeches to be conducted and/or finalized (ibid.).

${ }_{32}$ One can leave an implicit understanding (or explicit if so desired) that it was the limit point that it was possible to advance and, thus, accept it.
} 
Acevedo Díaz, J.A. (2008). El estado actual de la natureza de la ciencia em la didactica de las ciencias. Eureka Enseñanza Divulgacion Cientifica, 5(2), 134-169.

Allchin, D. (2004). Pseudohistory and pseudoscience. Science \& Education, v..13, 179-195.

Allie, S., Buffler, A., Loveness, K., Campbell, B., \& Lubben, F. (1998). First year physics students' perceptions of the quality of experimental measurements. International Journal of Science Education, 20(4), 447-459.

Amaral, I. A. (1997, dezembro). Conhecimento formal, experimentação e estudo ambiental. Ciência \& Ensino, 3, 10-15.

Andersson, G. (1984). ¿Son Compatibles Falsacionism y Falibilism? In Feyerabend, P.; Radnitzky, G., Stegmüller, W., y otros: "Estructura y desarrollo de la ciencia". 215-232, Alianza Editorial: Madrid.

Apostolou, A. \& Koulaidis, V. (2010, may). Epistemology and Science education: study of epistemological views of teachers. Research in Science \& Technological Education, 28, 149-166.

Araújo, M. S. T. \& Abib, M. L. V. S. (2003, junho). Atividades experimentais no ensino de Física: diferentes enfoques, diferentes finalidades. Revista Brasileira de Ensino de Física, 25(2), 176-194.

Biscaino, A. P. \& Camargo, S. (2012). O que dizem os principais eventos da área de ensino de física com relação às atividades experimentais. Ciência em Tela, 5, 1- 9.

Cachapuz, A. F. et al. (2000). Perspectivas de ensino de ciências. In Cachapuz A. F. (Org.).

Perspectivas de ensino. Porto: Centro de Estudos de Educação em Ciência.

Camargo, S. (2003). Prática de Ensino de Física: marcas de referenciais teóricos no discurso de licenciandos. Dissertação (Mestrado em Educação para a Ciência). Faculdade de Ciências, UNESP, Bauru.

Chalmers, A. F. (1994). A Fabricação da Ciência. Editora Unesp: São Paulo.

Chinelli, M. V.; Ferreira, M. V. S., \& Aguiar, L. E. V. (2010). Epistemologia em sala de aula: a natureza da ciência e da atividade científica na prática profissional de professores de ciências. Ciência \& Educação, 16(1), 17-35.

Delizoicov D. (1996, dezembro). Editorial - Sobre a produção do conhecimento científico.

Caderno Catarinense de Ensino de Física, 13(3), 182-183.

Ferreira, N. C. (1978). Proposta de laboratório para a escola brasileira: um ensaio sobre a instrumentação no ensino de Física. Dissertação (Mestrado em Ensino de Ciências) - IFUSP/FEUSP. São Paulo.

Galiazzi, M. C. \& Gonçalves, F. P. (2004). A natureza pedagógica da experimentação: uma pesquisa na licenciatura em química. Química Nova, 27(2), 326-331.

Giordan, A. (1999). Une didactique pour les sciences expérimentales. Paris: Éditions Belin.

Hanson, N. R. (1975). Observação e Interpretação. In: Filosofia da Ciência. Editora Cultrix: São Paulo.

Higa, I. \& Oliveira, O. B. (2012, abri/jun). A experimentação nas pesquisas sobre o ensino de Física: fundamentos epistemológicos e pedagógicos. Educar em Revista, 44, 75-92. 
Hodson, D. (1998). Is this really what scientists do? Seeking a more authentic science in and beyond the school laboratory. In Wellington, J. (Ed.). Practical work in school science: Which way now?. Londres: Routledge, 93-108.

Kaline, S. O. (2015). O ensino por investigação: Construindo possibilidades na formação continuada do professor de ciências a partir da ação-reflexão. Dissertação de mestrado apresentada ao Programa de Pós-graduação em Ensino de Ciências e Matemática da Universidade Federal do Rio Grande do Norte como requisito para obtenção do título de mestre em Ensino de Ciências Naturais e Matemática. Natal - RN.

Kuhn, T. S. (1994). Lógica da descoberta ou psicologia da pesquisa? In Lakatos e Musgrave (Eds.): A Crítica e o Desenvolvimento do Conhecimento. Cultrix/EDUSP, p.5-32: São Paulo, 1970.

Kuhn, T. S. A Estrutura das Revoluções Científicas. $3^{\text {a }}$ Edição. Editora Perspectiva S.A:

São Paulo.

Labatini-Terra, L.; Larentis, A. L.; Atella, G. C.; Caldas, L. A.; Ribeiro, M. G. L.; Herbst, H. \& Almeida, R. V. (2014). Identificação de obstáculos epistemológicos em um artigo de divulgação científica - entraves na formação de professores de ciências? Revista Electrônica de Enseñanza de las Ciencias, 13(3), 318-333.

Laburú, C. E. (2003). Problemas abertos e seus problemas no laboratório de Física: uma alternativa dialética que passa pelo discurso multivocal e univocal. Investigações em Ensino de Ciências. 8(3), 231-256.

Lakatos, I. (1970). O Falseamento e a Metodologia dos Programas de Pesquisa Científica. In Lakatos \& Musgrave (Eds.): A Crítica do Desenvolvimento do Conhecimento, 109-243. Cultrix/EDUSP: São Paulo.

Ledermann, N. G. (1992). "Student's and teacher's conceptions of the nature of science: a review of the research". Journal of Research in Science Teaching, 29(4), 331-359. Lôbo, S. F. (2012). O trabalho experimental no ensino de Química.

Química Nova, 35(2), 430-434.

Lubben, F. \& Millar, R. (1996). Children's ideas about the reliability of experimental data. International Journal of Science Education, 18(8), 955-968.

Maldaner, O. A. (2000). A formação inicial e continuada de professores de química: professor/pesquisador. Ijuí: UNIJUÍ.

Marsulo, M. A. G. \& Silva, R. M. G. (2005). Os métodos científicos como possibilidade de construção de conhecimentos no ensino de ciências. Revista Electrônica de Enseñanza de las Ciencias. 4(3).

Matthews, M. R. (1994). Science Teaching - The role of history and philosophy of science. New York: Routledge.

Millar, R. (1991). A means to na end: The role of processes in science education. In Woolnough, B. (Ed.). Practical science. Milton Keynes: Open University, p.44-52.

Moreira, M. A. \& Massoni, N. T. (2016, abril). Interfaces entre visões epistemológicas e ensino e ciências. Ensino, Saúde e Ambiente, 9(1), 1-32.

Mortimer, E. F. \& Scott, P. (2002). Atividade discursiva nas salas de aula de ciências: uma ferramenta sociocultural para analisar e planejar o ensino. Investigações em Ensino de Ciências, 7(3), 283-306. 
Oliveira, M. M. L.; Costa, R. C.; Sotelo, D. G. \& Rocha Filho, J. B. (2010). Práticas experimentais de Física no contexto do ensino pela pesquisa: uma reflexão. Experiências em Ensino de Ciências, 5(3), 29-38.

Popper, K. R. (1970). A ciência normal e seus perigos. In Lakatos e Musgrave (Eds.): A Crítica e o Desenvolvimento do Conhecimento, 63-71. Cultrix/EDUSP: São Paulo. Popper, K. R. (1972). A Lógica da Pesquisa Científica. Editora Cultrix: São Paulo. Rosa, C. W. \& Rosa, A. B. (2010). Discutindo as concepções epistemológicas a partir da metodologia utilizada no laboratório didático de Física. Revista Iberoamericana de Educação, 52(6).

Sá, E. F.; Maués, E. R. \& Munford, D. (2008). Ensino de Ciências com caráter investigativo. I. In: Castro, E. C. de; Martins, C. M. de C.; Munford, D. (Orgs). Ensino de Ciências por investigação - ENCI: Módulo I. Belo Horizonte: UFMG/FAE/CECIMIG, 83-107. Silva, O. H. M. \& Laburú, C. E. (2016, julho). Implicações epistemológicas da aplicação de um método investigativo em aula experimental no ensino médio. Revista Electrónica de investigación en educación en ciencias, 11(1), 31-39. Whitaker, M. A. B. (1979). 'History and Quase-history in Physics Education, Pt I'. Physics Education, 14, 108-112. 